\title{
KNOWLEDGE AND ATTITUDES OF LOW BACK PAIN IN PHYSICIANS BASED IN CLINICAL PRACTICE GUIDELINES
}

\author{
CONHECIMENTO E CONDUTA EM CASOS DE LOMBALGIA COM BASE NAS DIRETIVAS DE \\ PRÁTICA CLINICA
}

\section{CONOCIMIENTOS Y ACTITUDES SOBRE LUMBALGIA DE MÉDICOS BASADOS EN LA GUÍA PRÁCTICA CLÍNICA}

Jorge Ruiz Sabido ${ }^{1}$, Edgar Reyes Padilla², Fátima Adriana Muñoz Carvajal ${ }^{3}$, José Manuel Pérez Atanasio ${ }^{4}$

\begin{abstract}
Objective: To determine the level of knowledge and attitudes of physicians in Tijuana based on Clinical Practice Guidelines (CPG) for the prevention, diagnosis and treatment of Nonspecific Low Back Pain (NLBP). Methods: Prospective, cross-sectional, descriptive study. Data were obtained from doctors who practice in clinics, private surgeries, and/or government institutions. Results: Of a total of 56 doctors surveyed, 37 were men and 19 women. None of the doctors said they had not seen a patient with Back Pain. 49\% knew the GPC, and $51 \%$ did not know of its existence. Conclusions: Although some physicians reported knowledge of the GPC, according to the results, there was a lack of full knowledge of, and adherence to these guidelines. Not knowing the GPC did not make it impossible to complete the questionnaire. The doctors felt more connected to the health system, but with less confidence in the management of cases of NLBP.
\end{abstract}

Keywords: Low back pain/prevention \& control; Low back pain/diagnosis; Low back pain/therapy; Orthopedics/standards, Practice guidelines as topic/standards.

\section{RESUMO}

Objetivo: Determinar o nível de conhecimentos e a conduta dos médicos de Tijuana, com base nas Diretivas de Prática Clínica (DPC) para prevenção, diagnóstico e tratamento da dor lombar não específica (DLNE). Métodos: Estudo prospectivo, transversal e descritivo. Os dados foram obtidos junto a médicos que prestam serviços em clínicas, consultórios particulares e/ou instituições governamentais. Resultados: Atingiu-se um total de 56 médicos entrevistados, dos quais 37 eram homens e 19 mulheres. Nenhum médico disse que não atende um paciente com dor lombar. Do total, 49\% conhecem as DPC e 51\% não sabiam da sua existência. Conclusões: Apesar de alguns médicos relatarem conhecer as DPC, de acordo com os resultados obtidos, falta-lhes maior domínio e conformidade com relação a essas diretivas. Não conhecer as DPC não impossibilita responder ao questionário. Os médicos sentem-se mais conectados ao sistema de saúde, mas com menos confiança na conduta em casos DLI.

Descritores: Dor lombar/diagnóstico; Dor lombar/prevenção \& controle; Dor lombar/terapia; Ortopedia/normas; Diretivas de prática clínica /normas.

\section{RESUMEN}

Objetivo: Determinar el nivel de conocimientos y las actitudes de los médicos en Tijuana, con base en la Guía de Práctica Clínica (GPC) para la prevención, diagnóstico y tratamiento del Dolor Lumbar Inespecífico (DLI). Métodos: Estudio prospectivo, transversal y descriptivo. Los datos fueron obtenidos de los médicos que prestan sus servicios en clínicas, consultorios privados y/o instituciones de gobierno. Resultados: Se obtuvo un total de 56 médicos encuestados, 37 hombres y 19 mujeres. Ningún médico contestó que no atiende un paciente con dolor lumbar. El 49\% conocen la GPC y el 51\% no saben de su existencia. Conclusiones: A pesar de que algunos médicos refieren conocer la GPC, según los resultados obtenidos falta mayor dominio y apego de la misma. El no conocer la GPC no hace imposible contestar el cuestionario. Los médicos se sienten más conectados con el sistema de salud, pero con menor autoconfianza en el manejo del DLI.

Descriptores: Dolor de la región lumbar/diagnóstico; Dolor de la región lumbar/prevención \& control; Dolor de la región lumbar/terapia; Ortopedia/normas; Guías de práctica clínica como asunto/normas.

\section{INTRODUCTION}

Low back pain (LBP) is the most common diagnosis of the locomotor system and it is estimated that around $80 \%$ of the population worldwide will suffer from it. It is recognized as the second most common reason for medical visits with a family medicine physician. ${ }^{1,2}$

Approximately $70 \%$ of LBP cases will never receive a specific diagnosis, despite a thorough clinical history and imaging studies. ${ }^{3-5}$ When the symptoms become chronic, it is called Nonspecific Low Back Pain
(NLBP) and accounts for an estimated 5 to $10 \%$ of cases. ${ }^{6,7}$

The costs associated with work disability and treatment add up to $75 \%$ of the resources targeted for lumbar pathology ${ }^{8}$ and approximately $30 \%$ of patients require disability leave. ${ }^{9}$

NLBP is diagnosed by exclusion and requires adequate knowledge of clinical skills and the timely application of correctly interpreted imaging studies, to avoid catastrophizing the images, thereby distinguishing mild from serious cases. ${ }^{2}$

1. Hospital Ángeles Tijuana,Tijuana, Baja California, Mexico.

2. Hospital de Traumatología, UMAE "Dr. Victorio de la Fuente Narváez", IMSS, Distrito Federal, Mexico.

3. School of Medicine, University of California, San Diego (UCSD), United States of America.

4. Hospital General de Zona, número 68, IMSS, Ecatepec, Estado de México. Mexico

Study conducted at the School of Medicine, Universidad Xochicalco,Tijuana campus, Mexico.

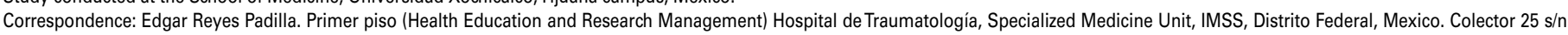
(Av. Fortuna) Esquina Av. Politécnico Nacional. Col. Magdalena de las Salinas, Deleg. Gustavo A. Madero. CP 07760. ed_kings@hotmail.com 
Wadell et $\mathrm{al}^{10}$ describe the variation in the number of disabilities per year caused by LBP in Great Britain, noting that even with the improvements in surgical technology and imaging techniques, and the improved precision in making anatomical diagnoses, treatment outcomes have worsened dramatically.

Meanwhile, Postigo et $\mathrm{al}^{11}$ reported an increase in the rate of surgical interventions in Great Britain as criteria were established in the images. They demonstrated that there is an underdiagnosed and undertreated cause of chronicity and disability that could be attributed to a psychosocial etiology.

Schecter et al, ${ }^{12}$ Moore et al, ${ }^{13}$ and Van der Windt et al ${ }^{14}$ defined the two treatment models commonly used for the treatment of low back pain as "medical and psychosocial". The former is associated with a good outcome when the diagnosis is specific and the latter, when the diagnosis is NLBP, through empowerment of the patient.

In the last years, standards and Clinical Practice Guidelines (CPG) have emerged and focused on improving the effectiveness and the efficiency of health care. ${ }^{15-18}$ Adherence to these guidelines has reduced the use of inefficient therapies, resulting in better outcomes and reduced costs. ${ }^{19}$

Despite evidence-based knowledge and the development of CPGs in European countries, the United Kingdom, Israel, Canada, and Mexico, improved results have not been reported, probably due to a lack of dissemination of information and adherence by doctors. ${ }^{20,21}$

In a survey of primary care physicians and orthopedists concerning the level of knowledge and adherence to the LBP CPGs, the orthopedists were not adequately prepared in terms of basic aspects, while primary care physicians were better prepared to deal with acute LBP. Both groups lacked knowledge about pharmacological treatment. ${ }^{22}$

In Mexico, two CPGs - "Diagnosis, treatment, and prevention of acute low back pain in primary care" and "Physiatric management of non-specific low back pain" - were published by the General Board of Health. However, there are no studies that document whether the health professionals that provide care for these patients either know about or adhere to them. ${ }^{23}$

Other researchers have studied and evaluated the attitudes, beliefs, and perceptions of the Physiatric professionals who care for patients with LBP and their impact on them. ${ }^{24,25}$ They report that beliefs, cultural factors, and education affect the decisions they make about these patients. . $^{3,26}$

Pincus et $\mathrm{al}^{20}$ developed and validated a tool to assess the knowledge of and attitudes about "Practices of the Musculoskeletal Apparatus" and applied it to different groups, concluding that professionals with a traditional education tend to focus on biomedical models, even though they would support a biopsychosocial approach. ${ }^{19,20}$

The objective of this study is to determine the level of knowledge and attitudes of doctors in Tijuana, Baja California, Mexico based on the CPG for the prevention, diagnosis, and treatment of NLBP.

\section{MATERIAL AND METHODS}

We conducted a cross-sectional study, study from November 2011 to August 2012. The data were obtained from clinical providers who provide services in clinics, private practices, and government institutions.

Inclusion criteria: qualified general physicians, family doctors, and physicians specialized in traumatology and orthopedics who treat patients with LPB and who signed the informed consent form. Exclusion criteria: doctors subspecializing in the spine.

A questionnaire was used for the convenience sampling. Data were collected by means of a structured questionnaire with 58 questions, including demographic (sex and age), behavioral (LBP background and educational activity), and workplace-related variables. The knowledge questionnaire consisted of 39 questions about epidemiology, clinical profiles, diagnosis, and treatment (Cronbach's alpha $=0.91$ ). To assess attitudes, 19 indicators were used to explore
6 dimensions: Limit on Sessions (LS), Psychology (P), Connection with the Healthcare System (CHS), Trust and Concern (TS); Reactivation (RA), and Biomedical (BM)..$^{16}$

In this study, reliability was estimated using the Kuder Richardson formula (for the knowledge tool) and Cronbach's Alpha (for the attitudinal tool, as a Likert scale was used) which reflects the consistency of responses of the group into a total for the respondents.

A descriptive analysis was performed. We used mean and standard deviation (abbreviated as SD) for continuous variables For categorical variables, frequencies and proportions expressed as percentages. The minimum and maximun range for the correct responses in the knowledge questionnaire was also identified. For qualitative variables, frequencies and proportions expressed as percentages were used.

Measurement of the level of knowledge about the CPG was based on the number of correct answers (out of a total of 39 responses), where $\leq 10$ points was defined as very little knowledge, 11-20 points as some knowledge, 21-30 points as fair knowledge, and 31-39 points as good knowledge. ${ }^{26}$ We used the statistical software STATA 11

For the process of adaptation and validation of the questionnaire, a group of subject matter experts met regularly to perform the translation and cultural adaptation of the base questionnaire. ${ }^{27}$ In addition, the group reviewed and reached a consensus on the relevant modifications, taking the following elements into account for the validation of the tool: content (the correlation between the number of responses and the weight assigned to the content of the $\mathrm{CPG}$ ) and "criterion and construct" (the ratio of the dimensions and their responses that correspond to the identification of knowledge about NLBP, according to the different areas of pathology).

\section{RESULTS}

A total of 56 clinical providers were surveyed, of whom 37 were men and 19 were women, with an average age of 44 years $(S D=12)$. There were no doctors who had not attended patients with LPB (0\%), 11 who had treated patients with LPB occasionally (20\%), 28 regularly (50\%), and 17 often (30\%).

In the population studied, 16 had teaching duties (29\%). In terms of where they worked, $17 \%$ worked in healthcare institutions, $59 \%$ in hospitals or private practices, and $25 \%$ in other locations.

The distribution of knowledge about CPG was 49\%, corresponding to 27 doctors, who knew about the existence of the CPG and $51 \%$, corresponding to 28 participants, who did not know about its existence. When asked how many times they had consulted the CPG, 37\% said they never had, $44 \%$ few times, $15 \%$ reported, and $5 \%$ often.

For the distribution of scores for level of LBP knowledge, based on the CPG, the following scale was used: very little knowledge (less than or equal to 10 points), some knowledge (11-20 points), fair knowledge (21-30 points), and good knowledge (31-39 points).

In terms of the knowledge, the dimension with the highest number of correct answers was clinical profile, followed by treatment, as shown in Table 1.

Attitudes were grouped by dimensions based on the article where the questionnaire was found, as shown in Table 2. In Table 3, the normal range for each dimension is shown and finally, in Figure 1, the averages of the attitudinal dimensions are displayed.

Table 1. Results of the knowledge questionnaire evaluating each dimension.

\begin{tabular}{c|c|c|c|c}
\hline Dimension & $\begin{array}{c}\text { Total } \\
\text { number of } \\
\text { questions }\end{array}$ & $\begin{array}{c}\text { Average number } \\
\text { of correct } \\
\text { answers }\end{array}$ & $\begin{array}{c}\text { Average \% } \\
\text { of correct } \\
\text { answers }\end{array}$ & $\begin{array}{c}\text { Minimum- } \\
\text { maximum range }\end{array}$ \\
\hline Epidemiology & 6 & 2.3 & $38 \%$ & $0-5$ \\
\hline Clinical profile & 15 & 7.5 & $50 \%$ & $0-12$ \\
\hline Diagnosis & 9 & 2.4 & $27 \%$ & $0-5$ \\
\hline Treatment & 9 & 4 & $44 \%$ & $0-7$ \\
\hline Total & 39 & 16 & $41 \%$ & $3-26$ \\
\hline
\end{tabular}


Table 2. Results of the survey of attitudes, presented by dimension.

\begin{tabular}{|c|c|c|}
\hline Attitudes & Average & SD \\
\hline Limit on Sessions & 22.4 & 3.1 \\
\hline $\begin{array}{c}\text { Yes, I continue to see my patients occasionally and } \\
\text { can prevent relapses }\end{array}$ & 4.98 & 1.64 \\
\hline $\begin{array}{l}\text { I believe that continuing patient treatment after the } \\
\text { pain has subsided can prevent relapses }\end{array}$ & 5.84 & 1.36 \\
\hline $\begin{array}{c}\text { Regular treatment by a physical therapist does not } \\
\text { prevent low back pain }\end{array}$ & 4.36 & 1.8 \\
\hline $\begin{array}{c}\text { If I keep seeing my patients from time to time } \\
\text { they will probably not learn to manage their pain } \\
\text { by themselves }\end{array}$ & 4.12 & 1.81 \\
\hline Psychological & 20.54 & 3.6 \\
\hline $\begin{array}{l}\text { It is essential that I find out about my patient's } \\
\text { psychosocial difficulties }\end{array}$ & 5.11 & 1.2 \\
\hline $\begin{array}{l}\text { I explore the psychosocial problems that my } \\
\text { patient is facing }\end{array}$ & 5.4 & 1.4 \\
\hline $\begin{array}{l}\text { I try to avoid questioning my patients about their } \\
\text { personal problems }\end{array}$ & 3.69 & 1.4 \\
\hline $\begin{array}{l}\text { I often find myself giving psychosocial support to } \\
\text { my patients }\end{array}$ & 5 & 1.2 \\
\hline Connection with the Healthcare System & 15.6 & 2.4 \\
\hline $\begin{array}{l}\text { When I refer my patients, I am confident that they } \\
\text { will receive good treatment }\end{array}$ & 5.75 & 1.39 \\
\hline $\begin{array}{c}\text { When I refer my patients, I know that they will be } \\
\text { seen within a suitable period of time }\end{array}$ & 5.15 & 1.4 \\
\hline $\begin{array}{c}\text { I do not view myself as connected to a health care } \\
\text { system as an accessible resource }\end{array}$ & 3.8 & 1.63 \\
\hline Trust and Concern & 7.3 & 2.6 \\
\hline $\begin{array}{l}\text { I do not think that anyone else can help my } \\
\text { patients with LBP better than I can }\end{array}$ & 3.0 & 1.71 \\
\hline $\begin{array}{l}\text { I am worried about the quality of treatment that } \\
\text { the patients whom I refer receive }\end{array}$ & 6.18 & 1.09 \\
\hline Reactivation & 14.04 & 3.8 \\
\hline $\begin{array}{c}\text { Return to the activities of daily life is the most } \\
\text { important outcome of treatment }\end{array}$ & 6.14 & 1.04 \\
\hline My goal is for the patient return to work soon & 5.45 & 1.64 \\
\hline $\begin{array}{l}\text { The most important objective of treatment is to } \\
\text { improve mobility }\end{array}$ & 5.09 & 1.22 \\
\hline Biomedical & 15.47 & 3.09 \\
\hline $\begin{array}{l}\text { I often have to teach patients to take care of their } \\
\text { backs }\end{array}$ & 5.7 & 1.15 \\
\hline $\begin{array}{l}\text { If you look carefully, you can find the structural } \\
\text { reason for low back pain in most patients }\end{array}$ & 5.96 & 1.19 \\
\hline $\begin{array}{c}\text { I recommend that my patients with low back pain } \\
\text { restrict their lifestyle }\end{array}$ & 4.36 & 1.79 \\
\hline
\end{tabular}

Table 3. Ranges of the scale of attitudes for LBP.

\begin{tabular}{c|c|c|c|c}
\hline Dimension & Range & Agree & Neutral & Disagree \\
\hline LS, P & $4-28$ & $21-28$ & $16-20$ & $<16$ \\
\hline CHS,RA,BM & $3-21$ & $15-21$ & $12-15$ & $<12$ \\
\hline TC & $2-14$ & $10-14$ & $8-10$ & $<10$ \\
\hline
\end{tabular}

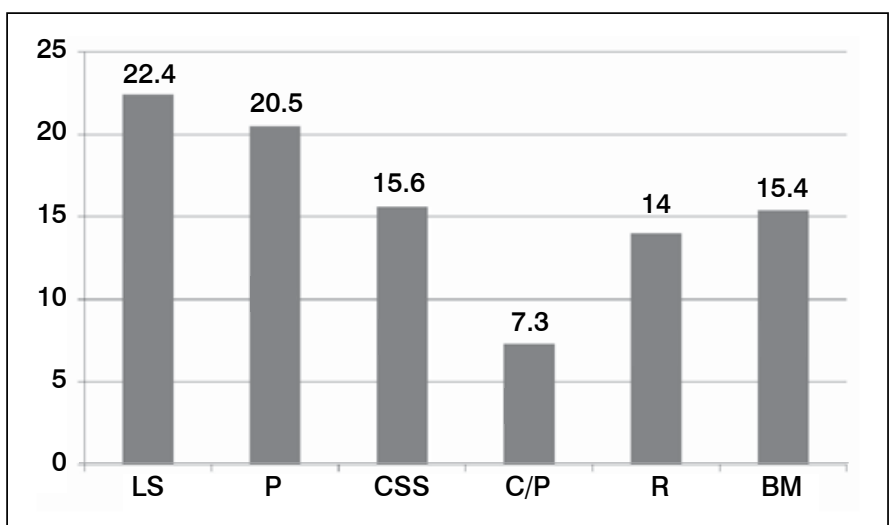

Figure 1. Average of the attitudinal dimensions of doctors who treat patients with NLBP.

\section{DISCUSSION}

Consistent with the literature, we found that all the doctors surveyed care for patients with LBP, $80 \%$ of whom do so regularly or often ${ }^{1,2}$. However, we can assume that most of them base their treatment on their own criteria and personal experience.

It is well known that LBP is one of the most common reasons for visits to primary care physicians. However, the results for patients and doctors are not often encouraging. This is due to the fact that in most cases, neither clinical nor imaging methods allow us to make a specific etiological diagnosis. In those where a diagnosis can be established, the known treatments do not often resolve the problem.

In recent years, attention has focused on patients with LPB and NLPB with adherence to the CPGs because, as tools based on clinical evidence, they are assumed to prevent inefficient treatments and optimize resources by reducing costs and the length of disability. Although the impact to the different areas that influence adherence to the CPG is not known, there are several guidelines that help to determine it.

With this study, we sought to determine whether doctors in our environment adhere to the recommendations of the CPG: $51 \%$ reported no knowledge of it, therefore poor results regarding level of knowledge were expected. The 4 areas that were evaluated (epidemiology, clinical profile, diagnosis, and treatment) all reported knowledge of $50 \%$ or less, with clinical profile and treatment scoring the highest, and epidemiology and treatment the areas most lacking. We infer that the knowledge that they have was acquired during training and medical practice.

Although LBP is reported as one of the most important issues, it is not often included in practical training, either at the undergraduate or specialization level.

In terms of attitudes towards patients with LPB, the doctors tended to agree with the idea that frequent consultations can prevent recurrence, whereas the desired behavior is to educate and empower their patients. However, it is recognized that prolonged physiotherapy as a way to avoid relapses is inefficient.

As for the psychological aspects, the doctors recognize and agree with the need to explore them and address them, although not strongly, as they report that the sometimes provide support to their patients.

The doctors mentioned feeling supported by the healthcare system, caring about the treatment their patients will receive from more specialized providers, and trusting that it will be adequate.

Finally, the doctors recognize that returning to work is one of the important factors in the treatment of patients with NLBP.

We recognize the importance of disseminating the CPGs to primary care physicians and orthopedists because there is insufficient knowledge about it. And while the willingness and attitudes in our environment are favorable to treating patients with NLBP, the level of knowledge is insufficient, leading to low self-confidence in performing this work, which probably results in referring patients to second and third levels of care without having first benefited from an evidence-based treatment that may be more suitable. 


\section{CONCLUSIONS}

Although some doctors reported knowledge of GPC, according to the results of the analysis, there is a lack of mastery of and adherence to it. The number of doctors who reported that they know about the CPG was not consistent with the number of those who reported they use it.

Not knowing about the CPG did not prevent them from responding to the questionnaire, probably because during their academic and clinical training they had acquired knowledge about approaches to and management of LBP.

The doctors surveyed had clinical knowledge about LBP, but limited criteria for diagnosis in accordance with the CPG, i.e. they knew how to identify the patient, but did not know the criteria for requesting imaging studies.

There were sociocultural differences between our population and those reported in the literature, but, in general, the attitudes were similar. However, we noted that our population feels more connected to the healthcare system, but with less self-confidence in the management of NLBP.

Use of this tool can sensitize doctors in addressing patients with NLBP and promote research on CPG for both knowledge and adherence.

\section{ACKNOWLEDGMENTS}

We thank the students of the Musculosketetal area of the Medical School of the Xochicalco Center for University Studies, Tijuana campus, particularly Alberto Apalategui Veitia, Cristabel Adriana Escobosa Rocha, and Daniel Fernando Zazueta Salido.

All authors declare no potential conflict of interest concerning this article.

\section{REFERENCES}

1. González C, Moscoso L, Ramírez G, Abdo A. Tratamiento multimodal para lumbalgia crónica inespecífica. Acta Ortop Mex. 2010;24(2):88-94

2. Saldivar $A H$, Cruz DL, Serviere L, Vázquez F, Joffre VM. Lumbalgia en trabajadores. Rev Med IMSS. 2003:41(3):203-9.

3. Koes BW, van Tulder MW, Thomas S. Diagnosis and treatment of low back pain. BMJ. 2006;332(7555):1430-4

4. ChavarríaY, Flores S, Martínez MG. Lo que el médico general debe saber sobre lumbalgia inespecífica. Rev Med Hondur. 2009;77(2):57-98

5. Kent PM, Keating JL, Taylor NF. Primary care clinicians use variable methods to assess acute nonspecific low back pain and usually focus on impairments. Man Ther. 2009:14(1):88-100.

6. Kent $P$, Keating JL. Classification in nonspecific low back pain: what methods do primary care clinicians currently use?. Spine (Phila Pa 1976). 2005 Jun 15;30(12):1433-40.

7. Zavala MA, Correa R, Popoca A, Posada SE. Lumbalgia en residentes de Comalcalco, Tabasco, México: Prevalencia y factores asociados. Arch Med. España. 2009;5(4). Disponível em: http://www.redalyc.org/pdf/503/50312946003.pdf

8. Humbría A, Carmona L, Peña JL, Ortiz AM. Impacto poblacional del dolor lumbar en España: resultados del estudio EPISER. Rev Esp Reumatol. 2002;29(10):471-8.

9. Covarrubias-Gomez A. Lumbalgia: un problema de salud pública. Rev Mex Anestesiol. 2010:30(1):S106-9

10. Wadell A. An historical perspectiva on low back pain and disability. Acta Orthop Scand Suppl. 1989;234:1-23.

11. Postigo TR. Síndrome de dolor lumbar crónico. Rev Med Clin Condes. 2007:18(3):239-45

12. Schecter S, Nordin M. Prevention and management of chronic back pain. Best Pract Res Clin Rheumatol. 2010;24(2):267-79.

13. Moore JE, Von Korff M, Cherkin D, Lorig K. A randomized trial of a cognitive-behavioral program for enhancing back pain self care in a primary care setting. Pain. 2000;88(2):145-53.

14. Van der Windt $D$, Hay E, Jellema P, Main C. Psychosocial interventions for low back pain in primary care", lessons learned from recent trials. Spine (Phila Pa 1976). 2008;33(1):81-9.

15. Castillo MS, Arias AR, Lleget MI, Ruiz BÀ, Escribà JJM, Gil M. Estudio epidemiológico de la lumbalgia. Análisis de factores predictivos de incapacidad. Rehabilitación (Madri). 2003;37(1):3-10
16. Dahan R, Borkan J, Brown JB, Shmuel R, Hermoni D, Harris S. Is the challenge of using the low back pain guidelines: a qualitative research. J Eval Clin Pract. 2007;13(4):616-20.

17. Bishop PB, Wing PC. Compliance with clinical practice guidelines in family physicians managing worker's compensation board patients with acute lower back pain. Spine J. 2003;3(6):442-50

18. Freeman MD. Clinical practice guidelines versus systematic reviews; which serve as the best basis for evidence-based spine medicine?. Spine J. 2010(6):512-3.

19. Fritz JM, Cleland JA, Brennan GP. Does adherence to the guideline recommendation for active treatments improve the quality of care for patients with acute low back pain delivered by physical therapists? Med Care. 2007;45(10):973-80.

20. Pincus T, Foster NE, Vogel S, Santos R, Breen A, Underwood M. Attitudes to back pain amongst musculoskeletal practitioners: a comparison of professional groups and practice settings using the ABS-mp. Man Ther. 2007;12(2):167-75.

21. Pincus T, Vogel $S$, Santos R, Breen A, Foster N, Underwood M. The attitudes to back pain scale in musculoskeletal practitioners (ABS-mp): the development and testing of a new questionnaire. Clin J Pain. 2006;22(4):378-86.

22. Finestone AS, Raveh A, Mirovsky Y, Lahad A, Milgrom C. Orthopaedists' and family practitioners' knowledge of simple low back pain management. Spine (Phila Pa 1976) 2009;34(15):1600-3.

23. Grupo Español de Trabajo del Programa Europeo COST B13. Guía de práctica clínica para la lumbalgia inespecifica. disponible en: www. REIDE.org. (visatada el 15 de diciembre de 2005.

24. Ostelon RWJG, Stomp SGM, Vlaeyen JWS, Wolters PMJC, de Vet HCW. Health care provider's attitudes and beliefs towards chronic low back pain: the development of a questionnaire. Man Ther. 2003;8(4):214-22.

25. Houben RM, Gijsen A, Peterson J, de Jong PJ, Vlaeyen JW. Do health care providers' attitudes towards back pain predict their treatment recommendations? Differential predictive validity of implicit and explicit attitude measures. Pain. 2005;114(3):491-8

26. Atlas SJ, Deyo RA. Evaluating and managing acute low back pain in the primary care setting. J Gen Intern Med. 2001;16(2):120-31.

27. Pantoja M, Barrera J, Insfrán M. Instrumento para evaluar aptitud clínica en anestesiología. Rev Med IMSS. 2003;41(1):15-22 